\title{
A Structural Equation Model for Analyzing the Impact of Strategic Management Accounting Techniques on Quality of Financial Information
}

\author{
Mohanad Fayiz Saleem AL-Dweikat ${ }^{1} \&$ Mohmoud Ibrahim Nour ${ }^{2}$ \\ ${ }^{1}$ Financial Management, Al-Isra University, Amman, The Hashemite Kingdom of Jordan \\ Correspondence: Mohanad Fayiz Saleem AL-Dweikat, Al-Isra University, The Hashemite Kingdom of Jordan. \\ E-mail: moh.dweikat@yahoo.com
}

Received: January 30, 2018

Accepted: February 14, $2018 \quad$ Online Published: February 28, 2018

doi:10.5539/ijef.v10n4p62

URL: https://doi.org/10.5539/ijef.v10n4p62

\begin{abstract}
This paper aims to analyzing the effect of strategic management accounting techniques on quality of financial information in private Jordanian universities in the capital, Amman. The study involves a questionnaire-based survey of dean and heads of department respondents from private Jordanian universities at Amman capital. A total of (212) valid questionnaire was finally obtained for analysis towards achieving the study objectives. Structural equation modeling was performed to understand the relationship between study variables. The results show that Benchmarking has a significant positive impact on Quality of Financial Information (Relevance, Understandability and Comparability). Value Chain Cost, also, has a significant positive impact on Quality of Financial Information (Relevance, Understandability and Comparability). As well as, Balanced Scorecard has a significant positive impact on Quality of Financial Information. This study displays the important role of strategic management accounting techniques in enhancing the Quality of Financial Information, as well as, helps decision makers to take their decisions based on Information Relevance, Understandability and Comparability.
\end{abstract}

Keywords: strategic management accounting techniques (SMAT), Quality of Financial Information (QOFI), private Jordanian universities and Structural equation modeling

\section{Introduction}

Many firms and institutions have suffered of the inability to accommodate benifits caused by the strategic management accounting techniques. The strategic management accounting techniques represented a substrate supporting for the management of firms and institutions to improve its competitive position on an ongoing basis through the information provided by the administration from its competitors, customers, suppliers and any other parties could affect the competitive position of the organization (Eze, 2009). Thus the role of strategic management accounting it dose not limited to provide the information to take decisions and carry out managerial functions, but even to facilitate, rationalization of managerial and strategic decisions taking process, as well as, completion of administrative strategies and interaction with other administrations within the organization. Thus, the objectives of the strategic management accounting techniques represented in creating an effective combination between the concept and scope of each of the investment, finance, profitability, control, evaluation and management accounting on order to achieve a sustainable competitive advantage. This is reflected that the financial reports of the organization must be characterized by their quality, that give the decision makers the ability for identify which business will granted to the organization a sustainable competitive advantage.

Cadiz and Building (2012) confirmed that the emergence of strategic management accounting techniques came with developments in the modern business environment, these developments led to increase management attention and focus on the concepts and techniques of strategic management accounting in order to create competitive advantages that help the administration to superiority its competitors.

Thus, the management accounting systems take a strategic dimension by applying a package of technologies and systems analysis in order to find appropriate and accurate accounting information for decision-makers (Langfield-Smith, 2008).

The structure of the current study consist of the study problem, its questions, Objective and Significance of the study, literature review, Study Hypothetical Model and Hypotheses Development, Study Design and 
Methodology, Analysis and Results, Conclusions and Implications.

\subsection{Problem of the Study}

The emergence of interest in strategic management accounting techniques came to a rationalizing the strategic decisions and one of the management accounting approach's which that illustrates the top management interests and strategies by placing the management accounting in the external perimeter, terms of use the financial information for the strategies development as a means to achieve and support the competitive advantage of the firms, as well as, the essential character of the strategic management accounting which interaction with other departments consisting of the firms (Cinquini \& Tenucci, 2010). According to the Yi and Taylor (2009) perspective, that the use of strategic management accounting techniques leads to discovery the improvement positions, added value for accounting systems development, support competitive advantages, collection and analysis the cost and price data, sales volume to examine the appropriateness of the firm competitive. Whereas, the strategic management accounting techniques lead to control of the business risks that may be exposed to the firms, which may cause in increased costs or volatility of profits (Brigham \& Houston, 2009). Consistent with the foregoing, many studies have addressed the traditional and strategic management accounting techniques applied in firms, uses, advantages and disadvantages of each of these techniques in different countries. The results varied from one country to another, but none of these studies did not delve into the research ot the impact of strategic management accounting techniques on Quality of Financial Information using structural equation model in the private Jordanian universities sector. So the current research problem represented in destitution and needed to conduct such studies in universities environment, on the other hand, to know the interest accruing from the application of strategic management accounting techniques and its role in improving the quality of financial information. The gap of the study emergent from the previous literature review that which made it clear that there was no study linking strategic management accounting techniques and quality of financial information.

\subsection{Questions of the Study}

Accordingly, it can represent the current research problem by raising the following question: To what extant the (benchmarking technique, Value Chain Cost technique and balanced scorecard technique) impact on quality of financial information (relevance, understandability and Comparability) in private Jordanian universities in the capital, Amman.

Derived the following sub-Questions:

1) To what extant the benchmarking technique impact on quality of financial information (relevance, understandability and Comparability) in private Jordanian universities in the capital, Amman?

2) To what extant the Value Chain Cost technique impact on quality of financial information (relevance, understandability and Comparability) in private Jordanian universities in the capital, Amman?

3) To what extant the balanced scorecard technique impact on quality of financial information (relevance, understandability and Comparability) in private Jordanian universities in the capital, Amman?

\subsection{Objective of the Study}

The aim of this study is analyzing the effect of strategic management accounting techniques on quality of financial information in private Jordanian universities in the capital, Amman through:

1) Examine the impact of benchmarking technique on quality of financial information (relevance, understandability and Comparability) in private Jordanian universities in the capital, Amman.

2) Investigate the impact of Value Chain Cost technique on quality of financial information (relevance, understandability and Comparability) in private Jordanian universities in the capital, Amman.

3) Investigate the impact of balanced scorecard technique on quality of financial information (relevance, understandability and Comparability) in private Jordanian universities in the capital, Amman.

\subsection{Significance of the Study}

The worth of the study stems from the Strategic management accounting techniques are a successful tools to the firms, regardless of the type of sector they belong to. In addition to emphasizing the importance of strategic management accounting techniques to achieve the quality of reports for firms or universities in order to benefit and learn from what has happened to many giant firms in many countries as a result of the false practices in the financial reports and the loss of credibility, which effect negatively on investors' confidence. 


\section{Literature Review}

\subsection{Strategic Management Accounting Techniques}

Atkinson, et al. (2004) explain that the history of strategic management accounting has two major facts:

1). The strategic management accounting driven with the development of the organization and its strategic imperatives.

2). The strategic management accounting systems it's developed by managers to determine the needs of the decision-making process, thus, the strategic management accounting must be pragmatic and that add value to the organization.

Duruy (2000) identifies a number of trends that the strategic management accounting working through it:

- Expand traditional management accounting techniques through internal focus that included external information about competitors.

- The relationship between strategic situation chosen by the organization and the expected focus by the management accounting (the accounting relationship with strategic situation).

- Achieve competitive priority through analysis of the ways to reduce the cost and / or encourage the differentiate products.

Cinquini and Tenucci (2010) explained that the strategic management accounting reflects a conceptual content of management accounting, which focus on the external aspects, therefore, the strategic management accounting focus on the provision of information relating to market end products, details about products, competitors and customers.

Cravens and Guilding (2001) define strategic management accounting as analysis of financial information related to markets products firms, production costs incurred by the competitors, cost structure and control of the firm's strategy to provide information on the firms market and its competitors.

On the other hand, Langfield-Smith (2008) defined strategic management accounting as providing and analysis the data of management accounting for the firm and its competitors to formulating and controlling the business strategy.

Based on above, the researchers adapt the three techniques: benchmarking, value chain cost and balanced scorecard because they are the most techniques widely used in Jordanian firms and institutions. The implications of these techniques have been determined based on Chinedu et al. (2014); AL-Nawayseh (2013).

\subsubsection{Benchmarking Technique}

The Benchmarking Technique reflect the process of improving performance through continuously identifying, understanding, and adapting outstanding practices and processes found inside and outside an organization. This mean the Benchmarking Technique represent an a approach for implementing best practices at best cost (Heizer \& Render, 2000). Horngren, et al. (2003) define Benchmarking Technique as thecontinuous process of comparing performance levels to manufacture the product or service and operational activities against the best units in the level of performance that can be found within the competing units or in units that perform similar operations. As well as, numerous studies dealt with benchmarking as a structured quality improvement technique (Braillon et al., 2008; Francis et al., 2008).

\subsubsection{Value Chain Cost Technique}

This Technique considers all the activities performed from the design to the distribution of the product. According to Value chain accounting is a 'product of the combination of the value chain management theory, accounting theory and information technology' (Kirli \& Gümüş, 2011).

\subsubsection{Balanced Scorecard Technique}

Kaplan \& Norton is the basis for the emergence and development of the idea of Balanced Scorecard, which coincided with the development of many concepts during the 1990s. Kaplan and Norton (2001) describe the Balanced Scorecard as a management technique designed to solve problems along with strategy transformation widely applied. Horngren et al. (2009) define the Balanced Scorecard as a way to transform the organization's mission and strategy into performance measures.

\subsection{Quality of Financial Information}

Quality of financial reporting is the main objective that organizations seek to achieve it. The enhancing the quality characteristics of financial reports can improve the benefit of decision when basic characteristics are 
established (Beest et al., 2009). Tang et al. (2008) define financial reporting quality as the extent to which the financial statements provide true and fair information about the underlying performance and financial position. A commonly accepted definition is provided by Jonas and Blanchet (2000), who argue that quality financial reporting is full and transparent financial information that is not designed to obfuscate or mislead users.

\subsection{The Relationship between SMAT and QOFI}

AL-Nawayseh (2013) clarify the extent of applying strategic management accounting tools in Jordanian banks, the tools tested are Competitor Analysis, Valuing Customers, Integrated Performance Measurement, Activity Based Costing, Life Cycle Costing, Managing and Budgeting, Cost of Quality, Balanced Scorecard, Benchmarking, Brand Value Monitoring, Strategic Pricing, Target Costing and Value Chain Costing, the investigate reveale that the Jordanian banks utilize traditional management accounting; they don't use strategic management accounting and its tools. Pavlatos (2015) examine the relationship between contextual factors; strategic management accounting and historical performance in hotels, the results reveale the perceived environmental uncertainty, structure, quality of information system, organizational life cycle stage, historical performance, strategy and size affect SMA usage in hotels. Ojua (2016) aims to review the extent of application of Strategic Management Accounting Practices in Nigerian manufacturing enterprises, The results indicated significant disapproval of Strategic Management Accounting Practices among professionals working in indigenous manufacturing enterprises. Agu et al. (2016) aims to determine the use of strategic management Accounting Techniques in sustainability Performance Measurement for Corporate Governance in Nigeria, the findings revealed the need for managers to employ strategic management accounting techniques to enable them identify, accumulate and manage social and environment costs of their activities for good corporate governance in Nigeria. Oboh and Ajibolade (2017) investigate the practicality of strategic management accounting adoption in banks in Nigeria, the results indicate the banks in Nigeria practice strategic management accounting as a principle of operation, and that strategic management accounting contributes significantly to strategic decision making in the area of competitive advantage and increased market share. Jbarah (2018) investigate the effect of Strategic Management Accounting Techniques in Taking Investment Decisions in the Jordanian Industrial Companies, the study reveale there is a significant effect of the strategic management accounting techniques in taking investment decisions in the Jordanian industrial companies.

\section{Study Hypothetical Model and Hypotheses Development}

Based on the literature review above the researchers proposed a Hypothetical Model and Hypotheses Development as clarify below. The Study Hypothetical Model in Figure 1. As can be seen in the figure, we hypothesize strategic management accounting techniques consisting of three techniques: benchmarking, value chain cost and balanced scorecard. These three techniques were modeled with Quality of Financial Information as the dependent variable.

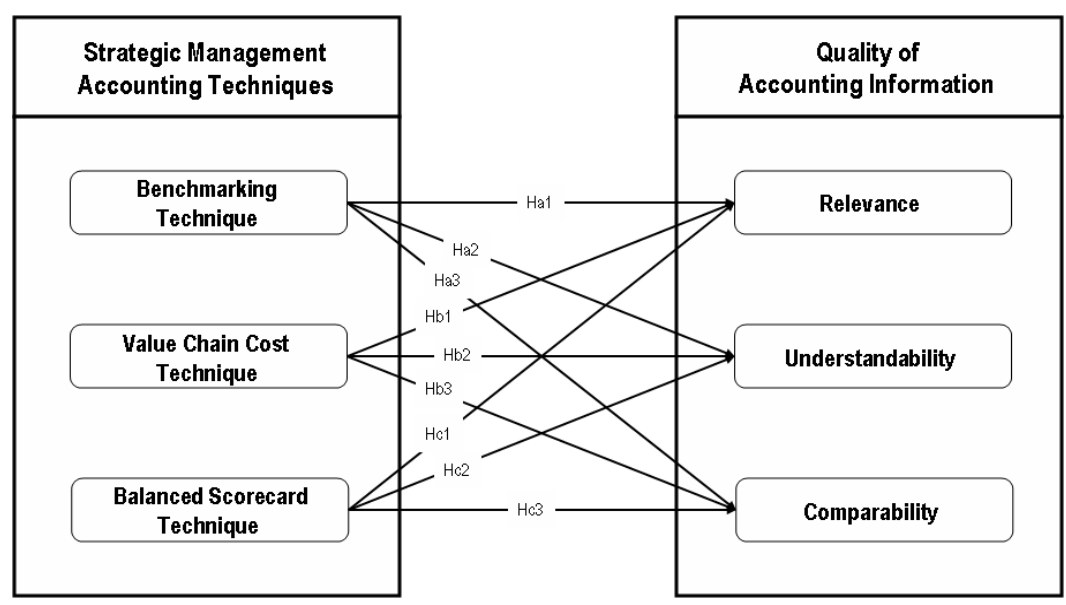

Figure 1. The study hypothetical model

We suggest strategic management accounting techniques to be significant determinant of Quality of Financial Information i.e. more strategic management accounting techniques lead to identify higher levels of Quality of Financial Information.

Based on hypothetical model above, the researchers development the following Hypotheses: 
Ha1: Benchmarking Technique has positive impact on Relevance.

Ha2: Benchmarking Technique has positive impact on Understandability.

Ha3: Benchmarking Technique has positive impact on Comparability.

Hb1: Value Chain Cost Technique has positive impact on Relevance.

Hb2: Value Chain Cost Technique has positive impact on Understandability.

Hb3: Value Chain Cost Technique has positive impact on Comparability.

Hc1: Balanced Scorecard Technique has positive impact on Relevance.

Hc2: Balanced Scorecard Technique has positive impact on Understandability.

Hc3: Balanced Scorecard Technique has positive impact on Comparability.

\section{Study Design and Methodology}

\subsection{Study Approach}

Investigation research was considering the mainly suitable technique of measuring the quantitative data (Neuman, 2003). Leedy and Ormrod (2005) defined Investigation research as gathering of information about the subject of the object to be measured from the members of the study sample and analyzing their answers to series of questions that decide in advance.

\subsection{Study Procedure}

To gain the data from the study sample, Firstly, the researchers were Convenience sampling technique, which defines a statistical technique of illustration data by selecting people because of their availability or easy access (Welman et al., 2005). This technique was frequent until a exemplary sample had fulfilled the questionnaire. A copy of the questionnaire has been given to each responder in order to answer the questions on the questionnaire as best. Participation in the investigation was completely voluntary. All responses remain confidential and anonymous.

\subsection{Statistical Tools \& Data Analysis}

This study adopts numerous statistical techniques. These statistics included a descriptive tools such as mean and standard deviation as well as cronbach's alpha, was used to determine the internal consistency (reliability). Reliability should be (0.70) or higher to indicate adequate internal consistency (Hair, et al., 2006). Statistical Package for the Social Sciences and Amos Ver. 22 to to verify study variables strategic management accounting techniques and Quality of Financial Information. As well as correlations, structural equation modeling was performed to understand the relationship and effects among these variables

\subsection{Measurement}

This study required developing a strategic management accounting techniques scale and Quality of Financial Information scale. As discussed in the above section, we have identified strategic management accounting techniques to be three techniques: (benchmarking, value chain cost and balanced scorecard). This current study scale was adapting scale developed by Chinedu et al. (2014); AL-Nawayseh (2013) The scales measured in a five-point Likert-scale format from strongly disagree" (1) to "strongly agree" (5).The descriptive statistics of these techniques presented in Appendix (1). For Quality of Financial Information we use scale developed by Beest et al. (2009) via (5) items. The scales measured in a (5) point Likert-scale format from "strongly disagree" (1) to "strongly agree" (5). The descriptive statistics of Quality of Financial Information presented in Appendix (2).

\subsection{Study Population and Sample}

\subsubsection{Study Population}

The study population in the current study consisted of all individuals working in private Jordanian universities at Amman capital.

\subsubsection{Study Sample}

A convenience sample comprising (225) of dean and heads of department respondents from private Jordanian universities at Amman capital fulfilled the questionnaire, because they have the authority to make decisions. A total of (221) respondent returned questionnaires, of which (9) questionnaires were discarded due to the lack of some information. Thus, total of (212) valid questionnaires were finally obtained. 


\section{Analysis and Results}

\subsection{Reliability, Correlations and Descriptive Statistic}

Hair et al. (2006, p. 137) introduce reliability as "an assessment of the degree of consistency between multiple measurements of a variable". Indeed, reliability indicates the dependability and consistency in research findings. In the same context, according to Hair et al. (2006), reliability of any survey instrument can be achieved if the repeated application of the instrument gave consistent results. The result obtained for Cronbach's alpha test, Correlations and Descriptive statistic for the variables are depicted below in Table 1. Cronbach alpha reliability coefficients are at acceptable levels and fall between (0.815) for the Comparability scale and (0.842) for Balanced Scorecard. The overall questionnaire presented a Cronbach alpha of (0.938).

Table 1. Cronbach's alpha test, correlations and descriptive statistic

\begin{tabular}{|c|c|c|c|c|c|c|c|c|c|c|}
\hline Variables & $\begin{array}{l}\text { No. of } \\
\text { ítems }\end{array}$ & $\begin{array}{l}\text { Cronbach } \\
\text { alpha }\end{array}$ & Mean & SD & Benchmarking & $\begin{array}{c}\text { Value Chain } \\
\text { Cost }\end{array}$ & $\begin{array}{l}\text { Balanced } \\
\text { Scorecard }\end{array}$ & Relevance & $\begin{array}{c}\text { Understand- } \\
\text { ability }\end{array}$ & Comparability \\
\hline Benchmarking & 4 & 0.817 & 3.607 & 0.926 & - & & & & & \\
\hline Value Chain Cost & 4 & 0.825 & 3.553 & 0.762 & $0.745^{* *}$ & - & & & & \\
\hline $\begin{array}{l}\text { Balanced } \\
\text { Scorecard }\end{array}$ & 4 & 0.842 & 3.530 & 0.763 & $0.522 * *$ & $0.483^{* *}$ & - & & & \\
\hline Relevance & 4 & 0.814 & 3.214 & 0.653 & $0.198 * *$ & $0.216^{* *}$ & $0.400^{* *}$ & - & & \\
\hline Understandability & 4 & 0.801 & 3.567 & 0.742 & $0.904 * *$ & $0.827 * *$ & $0.623^{* *}$ & $0.225^{* *}$ & - & \\
\hline Comparability & 4 & 0.815 & 3.423 & 0.908 & $0.454 * *$ & $0.416 * *$ & $0.913 * *$ & $0.436^{* * *}$ & $0.535 * *$ & - \\
\hline
\end{tabular}

** Correlation is significant at the 0.01 level (2-tailed).

As can be seen in Table 1 with total mean scores (3.563) for total strategic management accounting techniques, wherever form the first technique of strategic management accounting techniques - Benchmarking - as can be seen in Table 1, with mean scores (3.607). Form the Second dimension of strategic management accounting techniques - Value Chain Cost - as can be seen in Table 1, with mean scores (3.553). On the other hand, from strategic management accounting techniques - Balanced Scorecard, with mean scores (3.530). the total mean scores (3.401) for Quality of Financial Information. As well as the mean scores of Understandability were (3.567). The mean scores of Comparability were (3.423). Finally, the mean scores of Relevance were (3.214). From the other side, Table 1 clarifies the correlation coefficients between study variables. Where it is clear that the highest values correlated were among Balanced Scorecard and Comparability value of $\left(0.913^{* *}\right)$, with the lowest values correlated between Benchmarking and Relevance value of $(0.198 * *)$.

\subsection{Hypotheses Testing}

A structural equation modeling (SEM) was performed to test the hypotheses. The model shown in Figure 2 was was tested and provided good indicators of fit as: $\chi 2 / \mathrm{df}=2.934$, with the goodness of fit index (GFI) and adjusted goodness of fit index (AGFI) was 0.995 and 0.904, the normed fit index (NFI) was 0.998, the Tucker-Lewis coefficient (TLI) was 0.978, as well as, the comparative fit index (CFI) was 0.999 and the root mean square error of approximation (RMSEA) was 0.066 , indicating a good fit between the theoretical model and the data. As shown in table 2.

Table 2. Overall fit indices of structural model with all constructs

\begin{tabular}{ccccccccccc}
\hline Model & $\chi 2$ & $\mathrm{df}$ & $\mathrm{P}$ & $\chi 2 / \mathrm{df}$ & GFI & AGFI & NFI & TLI & CFI & RMSEA \\
\hline Default model & 2.934 & 1 & 0.087 & 2.934 & 0.995 & 0.904 & 0.998 & 0.978 & 0.999 & 0.066 \\
Saturated model & 0.000 & 0 & & & 1.000 & & 1.000 & & 1.000 & \\
Independence model & 1333.754 & 15 & 0.000 & 88.917 & 0.335 & 0.070 & 0.000 & 0.000 & 0.000 & 0.645 \\
\hline
\end{tabular}

Figure 2, show the structural equation modeling for study variables. 


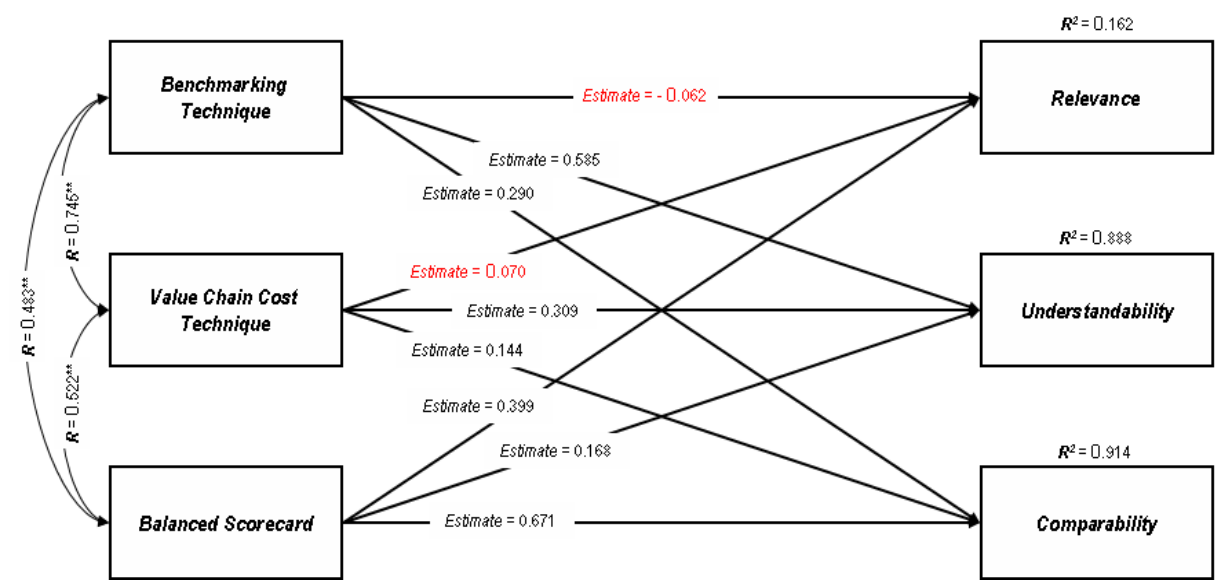

Figure.2 Result of a structural equation modeling (SEM)

Ha1: Benchmarking Technique has positive impact on Relevance.

Ha2: Benchmarking Technique has positive impact on Understandability.

Ha3: Benchmarking Technique has positive impact on Comparability.

A first effect represents the impact of a Benchmarking on a Quality of Financial Information (Understandability and Comparability). From Figure (2) and Table (3), shows that the Benchmarking has a significant impact on Understandability and Comparability $(\boldsymbol{\beta}=0.585, C . R=16.235, P$-value $=* * *$ and $\beta=0.290, C . R=9.237$, $P$-value $=* * *)$ or $\mathrm{Ha} 2$; Ha3 is supported.

Table 3. Affect testing result (benchmarking $\rightarrow$ relevance, understandability and comparability)

\begin{tabular}{|c|c|c|c|c|c|c|c|}
\hline \multirow{2}{*}{ Hypothesis } & \multicolumn{2}{|c|}{ Regression Weights } & \multirow{2}{*}{ Estimate } & \multirow{2}{*}{ SE } & \multirow{2}{*}{ C.R. } & \multirow{2}{*}{$P$ value } & \multirow{2}{*}{ Hypothesis } \\
\hline & From & To & & & & & \\
\hline Hal & Benchmarking & Relevance & -0.062 & 0.069 & -0.631 & 0.528 & Not Accepted \\
\hline $\mathrm{Ha} 2$ & Benchmarking & Understandability & 0.585 & 0.029 & 16.235 & $* * *$ & Accepted \\
\hline $\mathrm{Ha3}$ & Benchmarking & Comparability & 0.290 & 0.049 & 9.237 & $* * *$ & Accepted \\
\hline
\end{tabular}

Hb1: Value Chain Cost Technique has positive impact on Relevance.

Hb2: Value Chain Cost Technique has positive impact on Understandability.

Hb3: Value Chain Cost Technique has positive impact on Comparability.

A second effect represents the impact of a Value Chain Cost on a Quality of Financial Information (Understandability and Comparability). From Figure (2) and Table (4), shows that the Value Chain Cost has a significant impact on Understandability and Comparability $(\boldsymbol{\beta}=0.309, C . R=8.801, P$-value $=* * *$ and $\beta=0.144$, $C . R=4.708, P$-value $=* * *)$ or $\mathrm{Hb} 2 ; \mathrm{Hb} 3$ is supported.

Table 4. Affect testing result (value chain cost $\rightarrow$ relevance, understandability and comparability)

\begin{tabular}{|c|c|c|c|c|c|c|c|}
\hline \multirow{2}{*}{ Hypothesis } & \multicolumn{2}{|c|}{ Regression Weights } & \multirow{2}{*}{ Estimate } & \multirow{2}{*}{$\mathbf{S E}$} & \multirow{2}{*}{ C.R. } & \multirow{2}{*}{ Pvalue } & \multirow{2}{*}{ Hypothesis } \\
\hline & From & To & & & & & \\
\hline$H b 1$ & Value Chain Cost & Relevance & 0.070 & 0.082 & 0.725 & 0.468 & Not Accepted \\
\hline$H b 2$ & Value Chain Cost & Understandability & 0.309 & 0.034 & 8.801 & $* * *$ & Accepted \\
\hline$H b 3$ & Value Chain Cost & Comparability & 0.144 & 0.058 & 4.708 & $* * *$ & Accepted \\
\hline
\end{tabular}

Hc1: Balanced Scorecard Technique has positive impact on Relevance.

Hc2: Balanced Scorecard Technique has positive impact on Understandability.

Hc3: Balanced Scorecard Technique has positive impact on Comparability.

A thrid effect represents the impact of a Balanced Scorecard on a Quality of Financial Information (Relevance, Understandability and Comparability). From Figure (2) and Table (5), shows that the Balanced Scorecard has a significant impact on Relevance, Understandability and Comparability $(\beta=0.399, C . R=5.324, P$-value $=* * * ; \beta$ $=0.168, C . R=6.138, P$-value $=* * *$ and $\beta=0.671, C . R=28.025, P$-value $=* * *)$ or $\mathrm{Hc} 1 ; \mathrm{Hc} 2 ; \mathrm{Hc} 3$ is supported. 
Table 5. Affect testing result (balanced scorecard $\rightarrow$ relevance, understandability and comparability)

\begin{tabular}{|c|c|c|c|c|c|c|c|}
\hline \multirow{2}{*}{ Hypothesis } & \multicolumn{2}{|c|}{ Regression Weights } & \multirow{2}{*}{ Estimate } & \multirow{2}{*}{ SE } & \multirow{2}{*}{ C.R. } & \multirow{2}{*}{ P value } & \multirow{2}{*}{ Hypothesis } \\
\hline & From & To & & & & & \\
\hline Hcl & Balanced Scorecard & Relevance & 0.399 & 0.064 & 5.324 & $* * *$ & Accepted \\
\hline Hc2 & Balanced Scorecard & Understandability & 0.168 & 0.027 & 6.138 & $* * *$ & Accepted \\
\hline Hc3 & Balanced Scorecard & Comparability & 0.671 & 0.045 & 28.025 & $* * *$ & Accepted \\
\hline
\end{tabular}

\section{Conclusions and Implications}

This study provides an empirical study of the analyzing the impact of strategic management accounting techniques on quality of financial information in private Jordanian universities in the capital, Amman. We consider strategic management accounting techniques affected by quality of financial information. The results of the structural equation modeling provide support for the all hypotheses.Consistent with $\mathrm{Ha}$ Benchmarking Technique do not impact on report relevance in private Jordanian universities in the capital, Amman. As well as, the Benchmarking technique has positive impact on quality of financial information (Understandability and Comparability) in private Jordanian universities in the capital, Amman. This result is consistent with research result of Aksoylu and Aykan (2013) arguing that strategic management accounting techniques affected performance of large and medium enterprises.

In accordance with $H b$, Value Chain Cost Technique do not impact on report relevance in private Jordanian universities in the capital, Amman. As well as, the Value Chain Cost technique has positive impact on quality of financial information (Understandability and Comparability) in private Jordanian universities in the capital, Amman. This result is consistent with research result of Fowzia (2011) who emphasized that the strategic cost has a significant impact on achieving strategic efficiency.

Finally, with $H c$, Balanced Scorecard Technique has positive impact on quality of financial information (Relevance, Understandability and Comparability) in private Jordanian universities in the capital, Amman. This result is consistent with research result of Santini (2011) who emphasized that the strategic management accounting techniques has positive impact on financial information.

Therefore, private Jordanian universities in the capital, Amman decision makers can use the current findings to understand the role of strategic management accounting techniques in enhance quality of financial information. The current findings may be used by private Jordanian universities in the capital, Amman decision makers to improve the quality of their universities' long-term performance. To remain superiority and obtain highly performance, private Jordanian universities in the capital, Amman decision makers can try to increase improve the quality of their universities' long-term performance by systematic use to strategic management accounting techniques in the context their universities' and understanding the role of strategic management accounting techniques in enhance quality of financial information.

\section{References}

Agu, C., Nweze, A., \& Enekw, C. (2016). The Use of Strategic Management Accounting Techniques (SMATs) in Sustainability Performance Measurement for Corporate Governance in Nigeria. International Journal of Academic Research in Accounting, Finance and Management Sciences, 6(3), 262-271. https://doi.org/10.6007/IJARAFMS/v6-i3/2274

Aksoyl, S., \& Aykan, E. (2013). Effects of Strategic Management Accounting Techniques on Perceived Performance of Businesses. Journal of US-China Public Administration, 10(10), 1004-1017.

AL-Nawayseh, M. A. I. (2013). The Extent of Applying Strategic Management Accounting Tools in Jordanian Banks. International Journal of Business and Management, 8(19), 32-44. https://doi.org/10.5539/ijbm.v8n19p32

Atkinson, A., Kaplan, R. S., \& Young, M. S. (2004). Management Accounting (4th ed.). Prentice Hall, Pearson.

Beest, F. V., Braam, G., \& Boelens, S. (2009). Quality of Financial Reporting: Measuring qualitative characteristics. NiCE Working Paper 09-108, April, pp. 1-41. Retrieved from http://www.ru.nl/nice/workingpapers

Braillon, A., Chaine, F., \& Gignon, M. (2008). Le Benchmarking, une histoire exemplaire pour la qualité des soins. Annales françaises d'anesthésie et de reanimation, 27, 467-69. https://doi.org/10.1016/j.annfar.2008.05.009

Brigham, E., \& Houston, J. (2009). Fundamentals of Financial Management (12th ed.). Cengage Learning. 
Cadez, S., \& Guilding, C. (2012). Strategy, strategic management accounting and performance: A configurational analysis. Industrial Management \& Data Systems, 112(3), 484-501. https://doi.org/10.1108/02635571211210086

Chinedu, E. F., Ogbodo, O. C. Y., \& Onyali, C. I. (2014). Utilizing Strategic Management Accounting Techniques (SMATs) for Sustainability Performance Measurement. Research Journal of Finance and Accounting, 5(13), 140-153.

Cinquini, L., \& Tenucci, A. (2010). Strategic management accounting and business strategy: A loose coupling? Journal of Accounting and Organizational Change, 6(2), 228-259. https://doi.org/10.1108/18325911011048772

Cravens, K. S., \& Guilding, C. (2001). An empirical study of the application of Strategic Management Accounting Techniques. Advances in Management Accounting, 10, 95-124. DOI. http://hdl.handle.net/10072/3866

Drury, C. (2000). Management and Cost Accounting (5th ed.). Thamson, United States.

Eze, W. (2009). Strategic Management Accounting and Performance Measurement in Nigerian Hotels: A contingency-Based Study. A Master Thesis in Tourism and Hospitality Management, The Institute of Graduate Studies and Research, Eastern Mediterranean University, Gazimagusa-North Cyprus.

Fowzia, R. (2011). Strategic Management Accounting Techniques: Relationship with Business Strategy and Strategic Effectiveness of Manufacturing Organizations in Bangladesh. World Journal of Management, 3(2), 54-69. Retrieved from http://www.wjmpapers.com/static/documents/September/2011/4.\%20Rehana.pdf

Francis, R., Spies, C., \& Kerner, T. (2008). Quality Management and Benchmarking in Emergency Medicine. Current Opinion in Anaesthesiology, 21(2), 233-39. https://doi.org/10.1097/ACO.0b013e3282f5d8eb

Hair, J. F., Black, W. C., Babin, B. J., Anderson, R. E., \& Tatham, R. L. (2006). Multivariate Data Analysis (6th ed.). New York: Macmillion Publishing Company.

Hiezer, J., \& Render, B. (2000). Operations Management (6th ed.). Prentice Hell, New Jersey, U.S.A.

Horngren, C. T., Datar, S., Foster, G., Rajan, M., \&. Ittner, C. (2009). Cost Accounting: A Managerial Emphasis (13th ed.). New Jersey, Upper Saddle River: Prentice Hall.

Horngren, C. T., Foster, G., \& Datar, S. M. (2003). Cost accounting: A Managerial Emphasis (11th ed.). Printice-Hall international, Inc, New Jersy, U.S.A.

Jbarah, S. (2018). The Impact of Strategic Management Accounting Techniques in Taking Investment Decisions in the Jordanian Industrial Companies. International Business Research, 11(1), 145-156. https://doi.org/10.5539/ibr.v11n1p145

Jonas, G. J., \& Blanchet, J. (2000). Assesing Quality of Financial Reporting. Accounting Horizons, 3(14). https://doi.org/10.2308/acch.2000.14.3.353

Kaplan, R. S., \& Norton, D. P. (2001). Strategy-Focused Organization. How Balanced Scorecard Companies Thrive in the New Business Environment. Boston, Harvard University. https://doi.org/10.1108/s1.2001.26129cab.002

Kirli, M., \& Gümüş, H. (2011). The Implementation of strategic management accounting based on value chain analysis: Value chain accounting. from http://www.harungumus.com/ harungum/images/CV/icbmef-2011-9EYLUL.pdf

Langfield-Smith, K. (2008). Strategic management accounting: how far have we come in 25 years? Accounting, Auditing and Accountability Journal, 21(2), 204-228. https://doi.org/10.1108/09513570810854400

Leedy, P. D., \& Ormrod, J. E. (2005). Practical research: Planning and design (8th ed.).Upper Saddle River, NJ: Prentice Hall.

Neuman, W. L. (2003). Social Research Methods. Boston: Pearson Education.

Oboh, C., \& Ajibolade, S. (2017). Strategic management accounting and decision making: A survey of the Nigerian Banks. Future Business Journal, 3(2), 119-137. https://doi.org/10.1016/j.fbj.2017.05.004

Ojua, O. (2016). Strategic Management Accounting Practices among Indigenous Nigerian Manufacturing Enterprises. Open Science Journal, 1(2), 1-14. https://doi.org/10.23954/osj.v1i2.395

Pavlatos, O. (2015). An empirical investigation of strategic management accounting in hotels. International Journal of Contemporary Hospitality Management, 27(5), 756-767, 
https://doi.org/10.1108/IJCHM-12-2013-0582

Santini, F. (2013). Strategic Management Accounting and financial performance in the small and medium sized $\begin{array}{lllll}\text { Italian manufacturing } & \text { enterprises. Management }\end{array}$ https://doi.org/10.3280/MACO2013-001005

Tang, Q., Chen, H., \& Zhijun, L. (2008). Financial reporting quality and investor protection: A global investigation. Working Paper. https://doi.org/10.2139/ssrn.1290910

Welman, C., Kruger, F., \& Mitchell, B. (2005). Research Methodology (3rd ed.). Oxford: Oxford University Press.

Yi, M., \& Tayles, M. (2009). On the emergence of strategic management accounting: an institutional perspective. Accounting and Business Research, 39(5), 473-495. https://doi.org/10.1080/00014788.2009.9663379

\section{Apendix 1}

Descriptive statistics of three strategic management accounting techniques

\begin{tabular}{clcc}
\hline No. & strategic management accounting techniques & Mean & St.D \\
\hline 1 & We identify the outstanding practices from organizations anywhere & 3.745 & 1.114 \\
2 & We try to understand the outstanding practices from organizations anywhere & 3.514 & 1.064 \\
3 & We adapt the outstanding practices from organizations anywhere & 3.566 & 1.021 \\
4 & We compare the company's performance to an ideal standard & 3.603 & 0.935 \\
\hline & Mean \& St.D of benchmarking technique & 3.607 & 0.926 \\
\hline 5 & Value Chain Cost helps the company in costs management and improves the quality of the products & 3.448 & 0.964 \\
6 & Value Chain Cost helps the management in identifying unnecessary costs in production process & 3.481 & 0.970 \\
7 & Value Chain Cost helps in the development of competitive advantage for the company by reducing costs & 3.518 & 1.046 \\
8 & Value Chain Cost leads to increase the company profits in the strategic range & 3.764 & 0.761 \\
\hline \multicolumn{2}{c}{ Mean \& St.D of Value Chain Cost technique } & 3.553 & 0.762 \\
\hline 9 & Balanced scorecard assists to better improve of the measurement of strategic financial performance & 3.575 & 0.819 \\
10 & Balanced scorecard lead to the imposition of a good internal control & 3.650 & 0.820 \\
11 & Balanced scorecard provides strategic financial and non-financial performance measures & 3.419 & 1.038 \\
12 & Balanced scorecard link vision and strategy with growth and financial position & 3.476 & 1.004 \\
\hline \multicolumn{7}{c}{ Mean \& St.D of Balanced scorecard technique } & 3.530 & 0.763 \\
& Mean \& St.D of total strategic management accounting techniques & 3.563 & 0.697 \\
\hline
\end{tabular}

\section{Apendix 2}

Descriptive statistics of quality of financial information

\begin{tabular}{|c|c|c|c|}
\hline No. & Quality of Financial Information & Mean & St.D \\
\hline 13 & The relevance characteristic contributes in building expectations and predictions about the company future & 3.320 & 1.021 \\
\hline 14 & Our reports include financial and non-financial information & 3.292 & 0.968 \\
\hline 15 & Our firm uses fair value as measurement basis & 3.094 & 0.964 \\
\hline \multirow[t]{2}{*}{16} & Our firm report provides real results for business events & 3.150 & 0.879 \\
\hline & Mean \& St.D of Relevance & 3.214 & 0.653 \\
\hline 17 & Our firm report is a well organized & 3.566 & 1.021 \\
\hline 18 & Our firm balance sheet and income statement are clear & 3.603 & 0.935 \\
\hline 19 & Our firm report include graphs and tables & 3.448 & 0.964 \\
\hline \multirow[t]{2}{*}{20} & Our firm report included a comprehensive glossary & 3.650 & 0.820 \\
\hline & Mean \& St.D of Understandability & 3.567 & 0.742 \\
\hline 21 & In our firm the notes to changes in accounting policies explain the implications of the change & 3.419 & 1.038 \\
\hline 22 & In our firm the results of current accounting period are compared with results in previous accounting periods & 3.476 & 1.004 \\
\hline 23 & Information in the annual report in our firm is comparable to information provided by other organizations & 3.476 & 1.004 \\
\hline \multirow[t]{3}{*}{24} & The annual report in our firm presents financial index numbers and ratios & 3.320 & 1.021 \\
\hline & Mean \& St.D of Comparability & 3.423 & 0.908 \\
\hline & Mean \& St.D of total Quality of Financial Information & 3.401 & 0.602 \\
\hline
\end{tabular}

\section{Copyrights}

Copyright for this article is retained by the author(s), with first publication rights granted to the journal.

This is an open-access article distributed under the terms and conditions of the Creative Commons Attribution license (http://creativecommons.org/licenses/by/4.0/). 